\title{
CARUT MARUT PENEGAKAN HUKUM TERHADAP TINDAK PIDANA KORUPSI
}

\author{
Stefany Ismantara ${ }^{1}$, Raden Ajeng Diah Puspa Sari ${ }^{2}$, Cecilia Elvira ${ }^{3}$, Dr. Rahaditya ${ }^{4}$ \\ ${ }^{1}$ Fakultas Hukum, Universitas Tarumanagara Jakarta \\ Email: stefanism0404@gmail.com \\ ${ }^{2}$ Fakultas Hukum, Universitas Tarumanagara Jakarta \\ Email: radiahpuspa@gmail.com \\ ${ }^{3}$ Fakultas Hukum, Universitas Tarumanagara Jakarta \\ Email:ceciliaelvira2114@gmail.com \\ ${ }^{4}$ Fakultas Hukum, Universitas Tarumanagara Jakarta \\ Email:rahaditya@fh.untar.ac.id
}

\begin{abstract}
Corruption is the abuse of power for private gain that dangers various aspects in a country. Recently, corruption case that eroded the moral legitimacy of law enforcement officers had been revealed. The purpose of this article is to evaluate law enforcement against corruption by public officials in Indonesia as well as measures to overcome its problems effectively. The methodology used in this research is normative legal research which focused on secondary data approach. The injustice that includes weak sentencing regarding the bribery case of Pinangki Sirna Malasari had caught the public's attention for the lack of impactful sentencing. This injustice makes more potential corruptors who are ignorant of the law. Indonesia's law enforcement agencies are considered to have high tolerance for corruption cases, and this principle of conditional justice has become common knowledge for the people. Corruption has the potential to destroy the nation's morale, hinder economic development, and trigger anarchism. The government and society must synergize in instilling an anti-corruption mindset towards themselves and the younger generation. Surveillance towards government institutions must be strengthened with public participation. Intervention of president as the highest authority is needed when there's injustice under his realm of authority. Formulation of a supporting legislation and establishment of anti-corruption institutions in every government or state agencies are needed. In order to create a government that is free of corruption, realization of anti-corruption law in Indonesia had to be done seriously.
\end{abstract}

Keywords: Corruption; Law enforcement

Korupsi adalah penyalahgunaan kekuasaan untuk kepentingan pribadi yang membahayakan berbagai aspek kehidupan. Belum lama ini, terkuak kasus korupsi yang mengikis legitimasi moral aparat penegak hukum. Karya tulis ini bertujuan untuk mengkaji bagaimana penegakan hukum terhadap tindak pidana korupsi oleh oknum pejabat publik di Indonesia, serta langkah-langkah pemberantasan korupsi secara efektif. Metode penelitian yang digunakan dalam penyusunan artikel ini adalah metode penelitian hukum normatif yang berfokus pengumpulan data sekunder. Ketidakadilan tuntutan hukum akan kasus penyuapan Pinangki Sirna Malasari menyita perhatian publik karena tuntutan pidana yang kurang memadai terlepas dari pelanggaran kode etik yang dilakukan sebagai aparat penegak hukum negara.. Jika ketidakadilan ini terus terjadi, akan muncul banyak koruptor potensial bebal hukum yang menjadi awal bagi kehancuran negara. Apabila implementasi penegakan hukum tidak maksimal, maka nilai dari hukum tersebut akan berkurang. Lembaga penegakan hukum di Indonesia dinilai memiliki toleransi yang tinggi terhadap kasus korupsi, dan prinsip keadilan bersyarat ini sudah menjadi pengetahuan umum bagi rakyat. Korupsi dapat menghancurkan moral bangsa, menghambat pembangunan ekonomi, serta memicu anarkisme. Pemerintah dan masyarakat harus bersinergi dalam menanamkan pola pikir anti korupsi terhadap diri sendiri dan para generasi muda. Transparansi dan pengawasan terhadap lembaga-lembaga pemerintahan harus diperkuat dengan adanya partisipasi masyarakat. Presiden sebagai pemegang kekuasaan tertinggi wajib turun tangan ketika terdapat ketidakadilan yang terjadi di bawah rumpunnya. Dibutuhkan perumusan legislasi yang mendukung dan pembuatan lembaga pemberantas korupsi di setiap badan penyelenggara negara. Demi mengusahakan suatu pemerintahan yang bersih dari korupsi, penegakan hukum atas tindak pidana korupsi di Indonesia harus direalisasikan dengan sungguhsungguh.

Kata Kunci: Korupsi; Penegakan hukum 


\section{PENDAHULUAN}

\section{Latar Belakang}

Dalam pengertian sederhana, korupsi merupakan penyalahgunaan kekuasaan dan kepercayaan untuk kepentingan pribadi (Martini, 2019). Korupsi merupakan suatu kejahatan yang merampas hak rakyat, kejahatan luar biasa yang melawan kemanusiaan. Pelaku kejahatan yang melawan kemanusiaan sepatutnya dihukum secara adil dan berimpas, agar dapat memberikan efek jera kepada pelakunya, kepatuhan akan hukum bagi yang lain, dan keadilan bagi rakyat. Namun, realisasi akan penegakan hukum bagi para pelaku tindak pidana korupsi dinilai masih rendah hingga saat ini. Tidak ada peningkatan, yang ada hanyalah penjerumusan.

Uang rakyat yang telah terkorupsi tidak pernah dapat dikembalikan seratus persen, sementara hukuman pidana yang menjerat pelaku hanya berlaku sementara, bahkan seringkali terpotong. Apa pengurangan sanksi bagi koruptor memiliki tujuan luhur yang dapat menyentuh hati pelaku dan mendorongnya untuk berubah demi membangun negara? Dilihat dari kenyataan di lapangan, keputusan tersebut dibuat hanya untuk melindungi sejumlah elite politik yang korup, sekaligus menjadi alat untuk menjerakan rakyat.

Kasus-kasus penyuapan, gratifikasi, pencucian uang, dan lain sebagainya sudah sering terdengar di telinga masyarakat. Sebagian orang memahami, seperti itulah wajah manusia yang sebenarnya jika sudah terbelenggu uang dan kekuasaan. Namun, bagaimana jika orang yang melakukan praktik-praktik ilegal tersebut adalah seorang aparat penegak hukum yang seharusnya bekerja demi membela hak masyarakat dan menegakan hukum di negara ini?

Pinangki Sirna Malasari, seorang jaksa yang pada saat ini kedudukannya sebagai jaksa sudah dilepas dan statusnya telah berubah menjadi narapidana, terbukti melakukan tiga tindak pidana. Tindak pidana tersebut antara lain menerima suap sebesar 500 ribu dollar Amerika dari terpidana kasus cessie bank bali, Djoko Tjandra, yang sangat merugikan keuangan negara; melakukan pencucian uang senilai Rp5,253 miliar; dan melakukan permufakatan jahat untuk menggagalkan eksekusi Djoko Tjandra (Maharani, 2021). Beberapa petinggi kepolisian seperti Brigjen Pol Prasetijo Utomo, Brigjen Nugroho Slamet Wibowo, dan Irjen Napoleon Bonaparte juga ikut terlibat dalam kasus pembebasan dan penyuapan oleh terdakwa Djoko Tjandra. Pelanggaran kode etik jaksa dan kepolisian sebagai salah satu aparat penegak hukum ini semakin mengikis legitimasi moral aparat penegak hukum di mata rakyat.

Pinangki Sirna Malasari hanya dijatuhkan vonis 4 tahun penjara serta denda sebesar 600 juta rupiah pada putusan banding di Pengadilan Tinggi DKI Jakarta. Vonis yang diberikan tersebut telah dipotong enam tahun dari putusan yang diberikan pengadilan tingkat pertama oleh Majelis Hakim Pengadilan Tipikor Jakarta. Setelah mengumumkan putusan banding, kejaksaan memutuskan untuk tidak mengajukan kasasi kepada Mahkamah Agung. Disebutkan bahwa tuntutan jaksa penuntut umum dinilai telah terpenuhi dalam putusan majelis hakim Pengadilan Tinggi DKI Jakarta. Putusan pengadilan tersebut kurang sesuai dengan sanksi yang disertakan dalam ketentuan Pasal 11 UU 31/1999 mengenai penyuapan Pasal 15 jo Pasal 13 UU Tindak Pidana Korupsi terkait permufakatan jahat, dan Pasal 3 UU 8/2010 mengenai pencegahan dan tindak pidana pencucian uang.

Berdasarkan ketentuan dari Pasal 11 UU 31/1999, Pinangki yang pada saat itu sedang menjabat sebagai pegawai negeri seharusnya dapat dipidana dengan pidana penjara maksimal 5 tahun atas kasus penyuapan yang dilakukannya, ditambah Pasal 15 jo Pasal 13 UU Tipikor yang menyampaikan bahwa pelaku permufakatan jahat dapat jatuhkan hukuman maksimal 20 tahun penjara serta denda maksimal 1 milyar rupiah. Belum lagi Pasal 3 UU 8/2010 yang mengatur bahwa pelaku tindak pencucian uang dapat dipidana penjara maksimal 20 tahun serta denda maksimal Rp10.000.000.000,00. Lalu atas dasar apa Pinangki Sirna Malasari yang telah melanggar pasal berlapis mendapatkan keringanan, bahkan potongan hukuman atas perbuatan kriminalnya? 
Boyamin Saiman selaku koordinator Masyarakat Anti Korupsi Indonesia yang mengawal kasus Djoko Tjandra dan jaksa Pinangki mengatakan bahwa dari awal jaksa Pinangki sudah diperlakukan secara istimewa bahkan sebelum dilakukannya penyidikan. Sebelumnya, kasus ini bahkan sempat dipertimbangkan untuk diselesaikan hanya dengan mencopot jabatan yang bersangkutan. Beliau juga menyatakan bahwa Jaksa Pinangki sama sekali tidak mengakui kesalahannya sejak awal. Jika hal ini benar, maka alasan dan pembelaan dari majelis hakim dan jaksa penuntut umum adalah sebuah pembohongan publik.

Sebelum kasus tersebut, sudah banyak kasus korupsi dan suap-menyuap yang melibatkan pihakpihak dari aparat penegak hukum. Para aparat penegak hukum yang seharusnya membela hak rakyat, menyuarakan amarah korban, dan membela hukum itu sendiri justru menghina keadilan dengan memvonis koruptor perampok uang rakyat dengan hukuman yang remeh, tidak setimpal dengan apa yang telah diperbuat. Tidak jarang juga ditemukan pelecehan hukum oleh aparat penegak hukum itu sendiri seperti yang diketahui dari kasus mantan jaksa Pinangki Sirna Malasari dan beberapa petinggi kepolisian lainnya. UU Tipikor sendiri dibuat dengan konsiderans memberantas korupsi secara efektif, sebab tindakan korupsi merugikan keuangan negara yang berdampak buruk terhadap pembangunan ekonomi negara. Ketika tindakan korupsi yang dilakukan oleh oknum pejabat publik membuahkan kerugian yang lebih besar bagi negara, namun pada waktu yang sama merekalah yang kerap kali menjadi pengecualian pemidanaan yang pantas diberikan, bagaimana tujuan dari UU Tipikor tersebut dapat dilaksanakan secara optimal?

Sulit bagi masyarakat melupakan stigma polisi yang mudah disuap. Hal ini bukan hanya dikarenakan oleh berita-berita mengenai praktik pelanggaran hukum yang disebarkan melalui media massa, namun juga berdasar dari pengalaman pribadi masyarakat yang bertemu kejadian tak menyenangkan itu secara langsung. Contoh sederhananya adalah seperti polisi lalu lintas yang kerap kali menerima suap dari pengguna jalan yang ditilang.

Eksistensi harga diri dari hukum di Indonesia sudah hampir tidak ada di mata rakyat. Masyarakat terlampau lelah dengan kontribusi dari aparat pemerintah dan penegak hukum untuk membuat negara ini menjadi semakin korup. Kenyataan mengenai hukum yang tumpul ke atas dan tajam ke bawah bahkan sudah menjadi pengetahuan umum dalam kehidupan bermasyarakat. Jika masalah ini tidak kunjung ditindaklanjuti, akan ada banyak koruptor potensial bebal hukum di masa yang akan datang, dan lama kelamaan negara akan hancur dengan sendirinya.

Maka dari itu, penyusunan artikel ini bertujuan untuk memahami sekaligus mengevaluasi penegakan hukum terhadap tindak pidana korupsi yang telah dilakukan oleh oknum pejabat publik di Indonesia. Penulis berharap karya tulis ini dapat menyumbang kontribusi dalam mewujudkan suatu pemerintahan yang bebas korupsi demi memajukan pembangunan negara dan menyokong kesejahteraan rakyat. Artikel ini diharapkan dapat menambah wawasan serta dapat menjadi kritik yang membangun untuk pembaharuan hukum di Indonesia mengenai tindak pidana korupsi dan menjadi referensi pada penulisan-penulisan karya tulis ilmiah selanjutnya.

\section{Rumusan Masalah}

Dari berbagai kasus dan permasalahan yang ada, dapat diidentifikasikan masalah sebagai berikut.

1. Bagaimana penegakan hukum terhadap Tindak Pidana Korupsi yang dilakukan oleh oknum pejabat publik?

2. Apa saja langkah-langkah penegakan hukum yang harus dilakukan oleh negara dalam pemberantasan korupsi secara efektif?

\section{METODE PENELITIAN}

Penulisan artikel ini didasarkan pada metode penelitian hukum normative-empiris yang berfokus pada pengumpulan data sekunder yang meliputi bahan hukum primer dan sekunder. Penelitian 
bersifat deskriptif dengan menggunakan pendekatan kualitatif untuk mendapatkan pemahaman terhadap gejala-gejala.

\section{HASIL DAN PEMBAHASAN}

\section{Implementasi Undang-Undang Pemberantasan Tindak Pidana Korupsi}

Pembentukan UU merupakan hal yang krusial dalam suatu negara hukum. Undang-undang menjadi dasar legalitas bagi seluruh elemen negara dan wajib hukumnya untuk ditaati oleh seluruh warga negara yang memenuhi syarat, baik itu penyelenggara negara maupun warga sipil, juga masyarakat yang tinggal di negara yang bersangkutan.

Dalam Pasal 27 ayat 1 UUD 1945, dikatakan bahwa seluruh warga negara memiliki derajat dan kedudukan yang sama dihadapan hukum, serta wajib menjunjung tinggi hukum yang berlaku tanpa terkecuali. Telah disebutkan bahwa hukum tidak mengenal status sosial, materi, jenis kelamin, dan aspek-aspek lainnya. Makadari itu, pelanggaran terhadap Undang-Undang yang berlaku perlu disikapi dengan tegas sesuai dengan peraturan perundang-undangan yang ada. Jika implementasinya tidak maksimal, maka fungsi atau nilai dari suatu Undang-Undang tersebut akan berkurang dan menyebabkan ketidakefektifitasan hukum yang berlaku.

Jika ditinjau dari kasus korupsi yang pernah terjadi di Indonesia, efektifitas hukum terhadp pelaksanaannya di lapangan dinilai rendah. Beberapa kasus yang membuktikan pernyataan ini salah satunya adalah kasus penerimaan suap, pencucian uang, dan permufakatan jahat yang telah dilakukan oleh jaksa Pinangki Sirna Malasari seperti yang telah dijelaskan sebelumnya. Bagaimana putusan sanksi yang diberikan dapat melenceng dari peraturan perundang-undangan yang berlaku?

Jaksa Pinangki Sirna Malasari melakukan pelanggaran terhadap tiga buah pasal sekaligus. Pasalpasal yang dilanggar antara lain Pasal 11 UU 31/1999 atas kasus penyuapan, Pasal 15 jo Pasal 13 UU Tindak Pidana Korupsi terkait permufakatan jahat, dan Pasal 3 UU 8/2010 tentang pencegahan dan tindak pidana pencucian uang. (Radityo, 2021)

Esensi dari Pasal 11 UU 31/1999 adalah pegawai negeri yang menerima suap akan dipidana dengan pidana penjara satu sampai lima tahun dan denda berkisar antara lima puluh sampai dengan dua ratus lima puluh juta rupiah. Pasal 15 jo Pasal 13 UU Tipikor menyampaikan bahwa pihak yang melakukan permufakatan jahat dapat dijerat dengan maksimal hukuman dan denda berturut-turut 20 tahun penjara dan 1 milyar rupiah. Sementara Pasal 3 UU 8/2010 menjelaskan bahwa semua orang yang melakukan tindak pidana pencucian uang akan di pidana penjara selambat-lambatnya 20 tahun serta denda paling banyak sepuluh milyar rupiah.

Majelis Hakim Pengadilan Tindak Pidana Korupsi juga menambahkan bahwa Pinangki tidak kooperatif dalam penyelidikan. Beliau menyangkal tindak pidana yang dituduhkan dan menutupi keterlibatan pihak-pihak lain. Pinangki sebagai aparat penegak hukum dalam hal ini jaksa, juga tidak mendukung langkah negara dalam memberantas korupsi, Kolusi dan Nepotisme dengan melakukan pelanggaran terhadap Undang-Undang itu sendiri. Faktor-faktor tersebut seharusnya sangat berpotensi memberatkan hukuman yang akan dijatuhkan. Awalnya, Pengadilan Tindak Pidana Korupsi menjatuhkan vonis 10 tahun penjara dengan denda sebesar Rp600 juta kepada terdakwa Pinangki Sirna Malasari. Namun, setelah mengajukan banding ke Pengadilan Tinggi DKI Jakarta, yang bersangkutan mendapat potongan masa tahanan sebesar $60 \%$, menjadi empat tahun penjara. Putusan hakim Pengadilan DKI Jakarta ini dinilai tidak sesuai dengan ketentuan pasal-pasal yang berlaku. Pelanggaran pasal berlapis dengan sanksi pelanggaran masing-masing pasal yang cukup berat harusnya dapat menjerumuskan Pinangki ke dalam jerat masa tahanan yang lebih lama dalam putusan banding di jenjang pengadilan yang lebih tinggi.

Salah satu dalih peringanan hukuman Pinangki Sirna Malasari yang menyatakan bahwa Pinangki sebagai wanita harus mendapatkan perhatian, perlindungan, serta diperlakukan secara adil dinilai bertentangan dengan UUD 1945, Pasal 27 ayat (1) yang menegaskan bahwa perbedaan ras, 
budaya, status sosial, jenis kelamin, dan lain sebagainya tidak boleh melakukan diskriminasi dalam bidang hukum dan pemerintahan.

Selain itu, majelis hakim mengatakan bahwa terdakwa telah mengaku bersalah dan mengatakan menyesali perbuatannya serta ikhlas dilengserkan dari jabatannya, maka dari itu ia masih dapat diharapkan akan berperilaku sebagai warga negara yang baik. Namun, korupsi merupakan salah satu tindakan yang dilakukan dengan adanya niat atau kesengajaan, bukanlah suatu ketidaksengajaan. Pinangki yang menjabat sebagai jaksa yang memiliki kecakapan di bidang hukum melakukan tindakan korupsi dengan kesadaran bahwa hal tersebut adalah perbuatan yang salah. Korupsi disebabkan oleh berbagai faktor, yaitu faktor kepribadian; rusaknya lingkungan dari negara seperti sistem hukum, pengawasan, dan politik; dan pengaruh dari lingkungan kelompok atau organisasi. Dengan memberi diskon hukuman terhadap pelaku korupsi, secara tidak langsung sang hakim telah menciptakan lingkungan yang mendukung terhadap tindakan korupsi tersebut. Seseorang yang berbuat korupsi sudah memiliki sifat curang dalam dirinya. Maka, tidak ada jaminan bahwa sang pelaku tidak akan mengulangi perbuatannya.

Pertimbangan lainnya adalah terdakwa yang memiliki anak yang baru berusia 4 tahun seharusnya mendapat kesempatan untuk mengasuh dan memberi kasih sayang kepada sang anak yang masih berada dalam masa pertumbuhan. Namun, pada tahun 2016, seorang ibu bernama Rismaya menyusui ditangkap dan ditahan atas tuduhan pencurian emas pemilik rumah tempat ia menumpang (Jawa Pos, 2016). Pencurian itu dilakukannya atas alasan himpitan keadaan ekonomi. Dilihat dari sisi kemanusiaan, seharusnya sang ibu dapat dijadikan tahanan rumah supaya ia masih dapat menyusui anaknya yang masih berusia sepuluh bulan. Namun, alasan keringanan hukum yang diberikan kepada jaksa Pinangki yang telah tertulis sebelumnya tidak berlaku bagi Ibu Rismaya yang tidak memiliki jaringan luas dan kedudukan sosial yang tinggi. Keadaan memaksanya untuk menyusui anaknya di balik jeruji besi yang dingin.

Kejadian serupa juga dialami oleh seorang ibu menyusui lainnya. Isma Khaira yang merupakan salah seorang warga Desa Lhok Puuk, Kecamatan Seunuddon, Aceh Utara, Aceh, harus mendekam dalam ruang tahanan lapas Kelas 2B Lhoksukon atas tuduhan pencemaran nama baik kepala desa setelah mengunggah postingan rekaman video berdurasi 35 detik ke media sosial Facebook yang menampilkan keributan antara kepala desa dengan ibunya yang terjadi pada 6 April 2020 (Luthfan, 2021). Ia terpaksa membawa bayinya yang baru berusia 7 bulan bersamanya ke dalam lapas sebab bayi tersebut masih membutuhkan asi darinya.

Sang hakim juga menambahkan bahwa terdakwa tidak melakukan perbuatan tersebut seorang diri, namun ada keterlibatan dari pihak lain yang juga bertanggung jawab sehingga kadar kesalahannya mempengaruhi keputusan pemotongan masa tahanannya di Pengadilan Tinggi DKI Jakarta. Informasi tersebut secara tidak langsung memotivasi publik untuk mengundang lebih banyak orang dalam melakukan suatu tindak kejahatan.

Sanksi dari pelanggaran ketentuan yang tertera dalam UU yang berlaku diminimalisir sedangkan pengecualian yang seharusnya tidak tertera dalam peraturan perundang-undangan yang berlaku dijadikan salah satu argumentasi dibalik pembelaan tersebut. Putusan dan sikap dari pihak pengadilan terkesan melindungi mantan anggota kejaksaan tersebut membuat masyarakat mempertanyakan keadilan hukum yang sesungguhnya di Indonesia. Jika dibandingkan dengan pidana yang dengan mudah dijatuhkan kepada masyarakat golongan menengah ke bawah, maka perbedaan perlakuan yang berujung kepada keadilan bersyarat bagi seluruh rakyat Indonesia ini semakin nampak.

Indonesia Corruption Watch (ICW) menyebutkan, pada tahun 2020 terdapat total 1298 terdakwa terkait kasus korupsi di Indonesia. (Guritno, 2021), yang mengalami kenaikan lebih dari dua kali lipat dibandingkan jumlah kasus korupsi pada tahun 2019 yang mencapai 580 tersangka dengan total kerugian Rp8,04 triliun (Ramadhan, 2020). Dari 1.298 terdakwa tersebut, rata-rata hukuman pidana yang dijatuhkan hanya 3 tahun 1 bulan. Sementara kerugian yang ditanggung 
negara karenanya adalah sebesar Rp 56,7 triliun, naik tujuh kali lipat dari total kerugian yang dialami negara pada tahun sebelumnya, diikuti dengan nilai suap Rp 322,2 miliar. Pidana tambahan uang pengganti yang seharusnya diharapkan dapat menutupi kerugian yang timbul akibat tindak pidana ini, hanya berjumlah Rp19,6 Triliun dengan total nilai denda Rp156 miliar dari 1.298 terdakwa. Anggaran yang didapat pemerintah dari pembayaran pajak warga negara banyak terbuang untuk dikonsumsi sebagai subsidi koruptor.

Korupsi yang mengalami peningkatan saat pandemi disebabkan oleh proses penggunaan uang negara yang dilakukan secara darurat setelah pemerintah mengeluarkan anggaran dengan jumlah yang sangat besar, yakni hampir mencapai Rp700 triliun di tahun sebelumnya (ICW, 2021). Faktor transparansi dan akuntabilitas menjadi melemah akibat prosedur yang kacau. Pada saat yang sama, keluarnya UU 19/2019 melemahkan KPK yang merupakan satu-satunya lembaga hukum antikorupsi di Indonesia. Pasal 3 dari UU tersebut menyebut KPK sebagai lembaga negara dalam rumpun kekuasaan eksekutif yang membuat KPK menjadi kurang independen dalam menjalankan tugasnya. Dalam Pasal 1 ayat (6) juga mengubah status pegawai KPK menjadi ASN yang mengakibatkan anggotanya lebih mudah dihasut oleh kepentingan politik. Pasal 37B ayat (1) huruf b juga mengatur bahwa KPK harus mendapatkan izin dari Dewan Pengawas sebelum melakukan penyadapan, penyitaan, maupun penggeledahan. Adanya protokol kesehatan akibat pandemi COVID-19 juga membatasi fungsi pengawasan para jurnalis dan aktivis, sementara ancaman kriminalisasi oleh UU ITE juga ikut menghadang kontrol sosial terhadap pejabat negara.

\section{Langkah-langkah Penegakan Hukum terhadap Tindak Pidana Korupsi}

Bandwagon effect ialah suatu fenomena psikologis di mana seseorang bertindak hanya karena tindakan tersebut juga dilakukan oleh orang lain, dengan mengabaikan keyakinan mereka sendiri (Linda \& Bloom, 2017). Korupsi yang merajalela apabila tidak ditangani dengan tegas berdasarkan peraturan perundang-undangan yang berlaku akan menyebabkan bandwagon effect di kalangan pejabat dan apparat penegak hukum. Trend atau kebiasaan ini kemudian akan dipandang sebagai hal yang lumrah, dan para aparat penegak hukum akan tergoda untuk menyalahgunakan kekuasaan yang dimilikinya. Pada awalnya muncul rasa takut untuk melakukan korupsi dalam jumlah besar, namun lama kelamaan akan timbul keserakahan dan keberanian untuk meraup lebih dari yang 'dibutuhkan'.

Hukum yang sepele membuat pelaku kehilangan efek jera dan merasa bahwa mereka mempunyai hak istimewa sebagai seseorang dengan kekuasaan dan jaringan luas sehingga kepedulian akan hukum yang berlaku perlahan-lahan akan pudar. Korupsi menciptakan iklim ketamakan, selfishness, dan sinisism (Theobald, 1990). Hal ini akan berdampak ke generasi muda secara langsung. Akan timbul pribadi yang terbiasa tidak jujur dan tidak bertanggung jawab. Lama kelamaan permasalahan ini akan berujung ke kehancuran moral bangsa. Disamping itu, harga diri hukum di mata publik akan menurun. Konstitusi tidak lagi dilihat sebagai sarana untuk mencapai keadilan dan keteraturan, melainkan senjata untuk mencapai kekuasaan. Legitimasi pemimpin negara dan pemerintahan menghilang dalam pandangan masyarakat. Pemerintah akan sulit mendapatkan kembali kepercayaan rakyat yang sudah terbendung dalam apatisme.

Sektor ekonomi dan pembangunan akan sulit untuk berkembang. Dana yang dibutuhkan terkuras habis dan negara harus berhutang akibat anggaran yang tidak mencukupi. Penelitian yang dilakukan oleh Transparency International menunjukkan bahwa korupsi dapat mengakibatkan penurunan nilai investasi baik dari dalam maupun luar negeri, karena investor ragu untuk membayar biaya lebih besar untuk memperoleh izin dan keamanan akibat praktek penyuapan yang dianggap wajar. Banyak daerah yang terabaikan akibat alokasi dana yang tidak sesuai dengan rencana. Rakyat yang merasa kecewa dengan pemerintah akan melakukan tindakan anarkis dan terjadilah instabilitas sosial politik dan disintegrasi sosial. 


\section{Pembentukan pola pikir dan anggapan}

Terdapat pemahaman bahwa korupsi merupakan suatu budaya bangsa. Pemahaman tersebut menjadikan pola pikir yang sesat dan membuahkan apatisme atau ketidakpedulian terhadap keadaan negara. Banyak orang yang pasrah dengan keadaan dan takut untuk membuat perubahan. Pribadi yang mementingkan moral dan masih mempunyai kesadaran sosial pun enggan untuk maju membela kebenaran karena rasa takut akan menjadi musuh para elite politik yang berpikir secara pragmatis.

Pola pikir anti korupsi perlu diterapkan sejak dini untuk membentuk generasi yang berakal sehat. Nilai-nilai agama dan kesadaran sosial harus ditanamkan tidak hanya melalui teori, namun juga pada pengaplikasiannya di kehidupan sehari-hari. Pembentukan karakter dimulai dari lingkungan pertama, yaitu keluarga, dan akan terus berkembang sesuai dengan lingkup pergaulan dan lingkungan masyarakat yang ditinggalinya. Oleh karena itu, terdapat beberapa hambatan yang menyebabkan lemahnya realisasi dari pembentukan pola pikir yang dimaksud. Setiap keluarga memiliki aturan, prinsip, dan kebiasaan yang berbeda-beda. Pemerintah juga memiliki batasan dalam mengelola negara dan menetapkan aturan daerah yang ada. Pemerintah tidak dapat melakukan intervensi yang dianggap mengekang kebebasan individu. Adanya batasan akan kontrol yang dapat dilakukan dan respon masyarakat yang beragam dalam menerima perubahan menjadikan pembentukan karakter menjadi tidak maksimal.

2. Meningkatkan transparansi dan pengawasan dengan partisipasi masyarakat

Menurut laporan Transparency International, Denmark dan Selandia Baru menempati urutan pertama sebagai negara terbersih dari praktik korupsi di dunia sepanjang tahun 2020, sementara Indonesia menempati peringkat 102 (dari total 180 negara) (Rizaty, 2020). Dalam perwujudannya dalam rangka memberantas korupsi, Denmark menempatkan lembaga seperti KPK di setiap lembaga pemerintahnya. Apabila ada kecurigaan terhadap dugaan korupsi yang dilakukan oleh pihak tertentu, masyarakat dapat melapor dengan menghubungi saluran telepon yang terhubung ke lembaga yang bersangkutan. Saluran telepon tersebut menyala selama 24 jam sehingga masyarakat tak perlu ragu untuk langsung melaporkan kejanggalan yang disaksikan. Indonesia dapat berkaca dari pengelolaan administrasi yang telah dilakukan Denmark dalam menghadapi laporan dugaan korupsi yang diterima.

Denmark juga memperkenalkan skema keterbukaan yang mewajibkan para anggota parlemennya untuk mempublikasikan transaksi atau pengeluaran bulanan mereka. Laporan pendapatan dan pengeluaran anggaran pemerintah juga ikut diberitakan kepada publik agar masyarakat juga dapat terlibat secara aktif dalam proses pengawasan keuangan negara. Tujuan dari diberlakukannya transparansi dan sistem pengawasan yang melibatkan masyarakat ini adalah demi meningkatkan akuntabilitas pemerintah terhadap pengelolaan SDA dan SDM serta membangun kepercayaan rakyat dengan ketersediaan akses informasi yang dapat dipertanggungjawabkan.

3. Kepastian hukum dan pemberian sanksi yang tegas untuk memaksimalkan rasa jera

Dalam hal ini, pemegang kekuasaan yudikatif perlu memberikan sanksi pidana sesuai dengan peraturan perundang-undangan yang berlaku dengan mempertimbangkan kerugian yang ditimbulkan koruptor. Presiden sebagai pemegang kekuasaan tertinggi memiliki kapabilitas untuk memberhentikan para pejabat yang berada di bawah ranah eksekutif apabila kinerja atau keputusan yang diambil dalam melakukan pekerjaannya dianggap gagal untuk mewujudkan keadilan yang dijanjikan kepada rakyat. Presiden memiliki kekuasaan untuk membantu penegakan hukum di Indonesia dengan cara menghasilkan legislasi yang mendukung. Presiden dapat menggunakan kewenangannya yang luas dalam mengontrol pembantu pengelola 
pemerintahan. Dalam hal ini, apabila petinggi di lembaga peradilan dinilai gagal dalam menjalankan tugasnya, maka presiden perlu memberhentikannya.

Koruptor harus ditempatkan dalam sel dengan fasilitas sesederhana mungkin. Tradisi seperti pemberian upeti untuk merasakan kenyamanan dan hidup mewah selama masa tahanan perlu dihilangkan. Sanksi yang tegas harus dijatuhkan kepada petugas kepolisian yang menerima suap, dan masa tahanan bagi pemberi suap juga harus ditambahkan. Perlu dibuat larangan bagi mantan narapidana korupsi untuk menjabat sebagai pegawai negeri dan ditetapkan aturan pengembalian dana hasil korupsi dengan cara seperti memberlakukan kerja paksa dalam masa tahanannya dan membuat batas waktu pelunasan hutang akibat kerugian negara yang ditimbulkan atas korupsi yang dilakukan, dan apabila yang bersangkutan tidak dapat melunaskan hutangnya dalam jangka waktu yang diberikan, maka seluruh harta kekayaannya akan disumbangkan kepada negara. Jika belum mencukupi, hutang yang masih tersisa akan dibebankan kepada keturunannya.

Dalam rangka merealisasikan langkah-langkah pemberantasan korupsi tersebut, perlu dibuat suatu peraturan yang tetap mengenai lembaga pemberantas korupsi yang memberikan kemandirian disertai kebebasan yang menyeluruh untuk mencegah keterikatan dan hambatanhambatan bagi lembaga pemberantas korupsi tersebut dalam melaksanakan tugas dan fungsinya. Aturan yang memberatkan posisi koruptor yang sekaligus menjabat sebagai pejabat publik juga perlu dirumuskan dan pelaksanaannya harus dimaksimalkan. Dalam merumuskan peraturan tersebut, diperlukan bantuan ahli-ahli di bidang yang bersangkutan dan perwakilan organisasi yang aktif mendukung pemberantasan korupsi di Indonesia. Perumusan aturan tersebut harus dilakukan dengan memperhatikan aspek transparansi dan partisipasi publik sehingga masyarakat dapat ikut berkontribusi memberikan masukan dan kritik yang membangun tanpa mengesampingkan norma dan nilai yang berlaku dalam masyarakat serta nilai-nilai Pancasila sebagai dasar negara.

\section{KESIMPULAN DAN SARAN}

Penegakan hukum terhadap Tindak Pidana Korupsi yang dilakukan oleh pejabat publik masih belum optimal dilihat dari analisis salah satu dari berbagai kasus korupsi pejabat publik dan data tindak pidana korupsi yang dirilis oleh ICW. Penegakan hukum terhadap tipikor jika dibandingkan dengan penjatuhan hukuman terhadap rakyat kecil, sangat minim akan nilai keadilan. Implementasi UU Tipikor dinilai kurang efektif untuk mencapai tujuannya. Hal ini ditinjau dari data yang dilaporkan ICW pada tahun 2020 yang menunjukkan bahwa toleransi penegakan hukum akan kasus korupsi di Indonesia sangatlah tinggi, dibuktikan dengan keringanan rata-rata hukuman pidana yang dijatuhkan pada para koruptor. Jika kasus korupsi yang terjadi semakin marak akibat penegakan hukum yang tumpul kepada masyarakat golongan atas, pada akhirnya akan terjadi kekacauan dalam negara.

Dalam memerangi korupsi, langkah-langkah yang dapat dilakukan adalah menanamkan pola pikir anti korupsi sejak dini, peningkatan transparansi dan pengawasan oleh negara, penyertaan masyarakat masyarakat dalam pengawasan alokasi dan distribusi anggaran pemerintah, menghadirkan lembaga anti korupsi dalam setiap lembaga penyelenggara negara, serta penyusunan legislasi yang dapat menjamin kepastian hukum dan badan yudikatif yang efektif dalam memberantas korupsi. Dalam rangka memerangi korupsi, presiden sebagai pemegang kekuasaan tertinggi dalam suatu negara juga harus terlibat secara aktif dengan memanfaatkan kekuasaannya demi mencapai keadilan bersama. Pemberatan hukuman bagi para koruptor perlu diterapkan untuk menimbulkan efek jera.

\section{Ucapan Terima Kasih}

Dengan selesainya penyusunan artikel ini, penulis menyampaikan terima kasih kepada : 
1. Bapak Yuwono Prianto, S.H, M.H selaku dosen mata kuliah PLKH-1 yang selalu bersedia meluangkan waktu dan berkontribusi dalam menuangkan pikiran dan tenaga dalam membimbing penulis sehingga artikel ini dapat terselesaikan dengan baik.

2. Keluarga para penulis, yang memberikan dukungan baik moral, spiritual maupun material hingga artikel ini dapat terselesaikan.

\section{REFERENSI}

Cherry, K. 2020. "Bandwagon Effect as a Cognitive Bias". https://www.verywellmind.com/what-is-the-bandwagon-effect-2795895. Diakses tanggal 27 Agustus 2021 pukul 22:03.

Diveranta, A. 2020. "Sebagian Kaum Muda Sulit Melupakan Stigma Polisi yang Mudah Disuap". $\quad$ https://www.kompas.id/baca/polhuk/2020/07/01/sebagian-kaum-muda-sulitmelupakan-stigma-polisi-yang-mudah-disuap/. Diakses tanggal 25 Agustus 2021 pukul 10:15.

Guritno, T. 2021. "ICW: Sepanjang 2020 Ada 1.298 Terdakwa Kasus Korupsi, Kerugian Negara Rp 56,7 Triliun”. https://nasional.kompas.com/read/2021/04/09/18483491/icw-sepanjang2020-ada-1298-terdakwa-kasus-korupsi-kerugian-negara-rp-567. Diakses tanggal 26 Agustus 2021 pukul 17:00.

Halim, D. 2020. "Temuan ICW, Rata-rata Vonis Perkara Korupsi Hanya 3 Tahun di Semester 1 tahun 2020". https://nasional.kompas.com/read/2020/10/11/19070061/temuan-icw-ratarata-vonis-perkara-korupsi-hanya-3-tahun-di-semester-i-tahun. Diakses tanggal 25 Agustus 2021 pukul 10:30.

Indonesia Corruption Watch. 2021. "Laporan Akhir Tahun 2020 Indonesia Corruption Watch". Jawa Pos. 2016. "Ayah dan Ibu ditahan, Bayi 10 Bulan Ini Harus Ikut ke Penjara". https://www.jawapos.com/jpg-today/30/12/2016/ayah-dan-ibu-ditahan-bayi-10-bulan-iniharus-ikut-ke-penjara/. Diakses tanggal 25 Agustus 2021 pukul 11:43.

Luthfan. 2021. "Masih Menyusui, Terpidana UU ITE Bawa Bayi ke Lapas". https://www.kompas.tv/article/151698/masih-menyusui-terpidana-uu-ite-bawa-bayi-kelapas. Diakses tanggal 23 Agustus 2021 pukul 21:34.

Maharani, T. 2020. "Istimewanya Jaksa : Tuntutan Ringan, Potongan Hukuman, dan Penundaan Eksekusi". https://nasional.kompas.com/read/2021/08/02/12164271/istimewanya-jaksapinangki-tuntutan-ringan-potongan-hukuman-dan-penundaan?page=all. Diakses tanggal 23 Agustus 2021 pukul 21:16.

Maharani, T. 2021. "Dagelan Kasus Pinangki, Ketika Perantara Suap Dihukum Lebih Berat dari Jaksa Korup". https://nasional.kompas.com/read/2021/07/06/20584121/dagelan-kasuspinangki-ketika-perantara-suap-dihukum-lebih-berat-dari-jaksa?page=all. Diakses tanggal 23 Agustus 2021 pukul 23:11.

Martini. (2019). "Tantangan dan Peluang Penegakan Hukum dalam Pemberantasan Tindak Pidana Korupsi”. Solusi, 17(1), 70-75.

Khakim, M. (2017). "Penegakan Hukum dan Implementasi Pasal 27 Ayat (1) Undang-Undang Dasar 1945 tentang Persamaan Kedudukan di Hadapan Hukum". Konferensi Nasional Kewarganegaraan III, Yogyakarta, 11 November 2017, 353-357.

Muhlizi, A. F. (2014). "Revolusi Mental Untuk Membentuk Budaya Hukum Anti Korupsi". Jurnal Rechts Vinding: Media Pembinaan Hukum Nasional, 3(3), 453-464.

Muluk, H. 2008. "Psikologi Korupsi”. Jakarta: Seputar Indonesia (2 Mei 2008).

Napisa, S., \& Yustio, H. (2021). "Korupsi di Indonesia (Penyebab, Bahaya, Hambatan dan Upaya Pemberantasan, Serta Regulasi) Kajian Literatur Manajemen Pendidikan dan Ilmu Sosial”. Jurnal Manajemen Pendidikan dan Ilmu Sosial, 2(2), 564-568. 
Nugroho, WB. 2017. "Sosiologi Korupsi : Problem Homo Ludens dan Penciptaan Subyek Antikorupsi".

Nurhidyati, ZA. 2020. "Yuk!Belajar dari Denmark dalam Pemberantasan Korupsi". http://itjen.pu.go.id/single kolom/34. Diakses tanggal 26 Agustus 2021 pukul 18:30.

Radityo, M. 2021. "Divonis 10 Tahun, Jaksa Pinangki Dijerat 3 Pasal Sekaligus". https://www.merdeka.com/peristiwa/divonis-10-tahun-jaksa-pinangki-dijerat-3-pasalsekaligus.html. Diakses tanggal 23 Agustus 2021 pukul 23:01.

Rahma, A. 2018. "Korting Hukuman Pinangki Hakim: Punya Balita Layak Diberi Kesempatan Mengasuh". $\quad$ https://nasional.tempo.co/read/1472670/korting-hukuman-pinangki-hakimpunya-balita-layak-diberi-kesempatan-mengasuh/full\&view=ok. Diakses tanggal 23 Agustus 2021 pukul 21:14.

Ramadhan, A. 2020. "Catatan ICW, Tren Penindakan Korupsi Turun Jadi 271 Kasus". https://nasional.kompas.com/read/2020/02/18/16532131/catatan-icw-tren-penindakankorupsi-turun-jadi-271-kasus. Diakses tanggal 3 September 2021 pukul 21:00.

Republik Indonesia. 1999. Undang-Undang Republik Indonesia Nomor 31 Tahun 1999 Tentang Pemberantasan Tindak Pidana Korupsi. Jakarta: Komisi Pemberantasan Korupsi.

Republik Indonesia. 2001. Undang-Undang Republik Indonesia No 20 Tahun 2001 Tentang Perubahan atas Undang-undang No.31 Tahun 1999 tentang Pemberantasan Tindak Pidana Korupsi. Jakarta: Kementerian Perencanaan Pembangunan Nasional Republik Indonesia.

Republik Indonesia. 2019. Perubahan Kedua atas Undang-Undang Nomor 30 Tahun 2002 tentang Komisi Pemberantasan Tindak Pidana Korupsi. Jakarta: Badan Pemeriksa Keuangan.

Rizaty, M. A. 2020. "Demark dan Selandia Baru Negara Paling Bersih dari Korupsi pada 2020". https://databoks.katadata.co.id/datapublish/2021/07/27/denmark-dan-selandia-baru-negarapaling-bersih-dari-korupsi-pada-2020. Diakses tanggal 1 September 2021 pukul 21:13.

Suparman, F. 2020. "KPK Jelaskan Tak Jerat Juliari dengan Pasal 2 UU Tipikor". https://www.beritasatu.com/nasional/706689/kpk-jelaskan-tak-jerat-juliari-dengan-pasal-2uu-tipikor. Diakses tanggal 22 Agustus 2021 pukul 20:17.

Shihab, N. 2021, 4 Agustus. Jaksa Pinangki Korupsi Tapi Kok Masih Digaji - (Part 1)| Mata Najwa [Video]. Youtube. https://youtu.be/Cn3itb2RtX4.

Thea DA, A. 2020. "Sejumlah Indikator UU KPK Hambat Pemberantasan Korupsi". https://m.hukumonline.com/berita/baca/lt5f463b69e740f/sejumlah-indikator-uu-kpkhambat-pemberantasan-korupsi. Diakses tanggal 3 September 2021 pukul 22:04.

Weda, I. B. K. (2013). "Korupsi dalam Patologi Sosial: Sebab, Akibat dan Penanganannya Untuk Pembangunan di Indonesia”. Jurnal Avokasi, 3(2), 126-128. 